\title{
ナガスクジラのルジオリピン
}

\author{
高橋隆* ・橋本喬* 渡辺昭一郎** \\ 長谷川黎**. 原一 - 郎*** \\ * 北里研究所（港区芝白金三光町）**北里大学衛生学部（港区芝白金三光町） \\ *** 東京医科歯科大学教養部 (千葉県市川市)
}

\section{Cardiolipin of Fin Whale}

Takashi Takahashi*, Takashi Hashimoto*, Shoichiro Watanabe**, Rei HASEgawA** and Ichirō HARA***

* Kitasato Institute (Sankō-cho, Shiba-Shirogane, Minato-ku, Tokyo)

** Faculty of Hygenic Science, Kitasato University (Sankō-cho, Shiba-Shirogane, Minato-ku, Tokyo)

*** Tokyo Medical and Dental University. (Ichikawa, Chiba)

Cardiolipin was prepared from the frozen heart muscle of fin whale according to Pangborn's method. Every step in the course purification was pursued by T.L.C., and the sample after the last step showed only single spot corresponding to cardiolipin on T.L.C.

From chemical analysis it's characteristics were as follows: $\mathrm{P}(\%)-4.2 \%, \mathrm{~N}(\%)-<0.1, \mathrm{I}$.V. -107 .

There was no difference between the pattern of IR apectrum of ox cardiolipin and that of fin whale cardiolipin.

The composition of fatty acid calculated from the pattern of G.L.C. was as follows: Palmitic acid23.5\%, palmitoleic acid-4.5\%, Oleic acid-44.5\%, Linoleic acid-25.0\%, Linolenic acid-1.4\%, but the observed IV value did not coincide with that calculated from the composition of fatty acid based on G.L.C.

In comparison with ox cardiolipin, cardiolipin of fin whale was found adaptable to the antigen for the routin test for syphilis.

\section{1 緒 言}

クジラリン脂質についてはすでに五十嵐らの報告があ 门)，イワシクジラのカルジオリピンよう物質について も同氏の発表がある゙2。一方セミクジラ，ナガスクジラ などのクジラの体の各部の脂質, 脂肪酸分布について佐 野らが最近くわしく報告している3。

カルジオリピン (C.L. と略す) は Pangborn の単 離() 以来, 多くの報告があり ${ }^{5,6)}$, MacFarlane と Gr$\mathrm{ay}^{7)}$ はカルジオリピンの構造を Diphosphatidyl glycerol と決定した。また, これの類似化合物の合成も行な

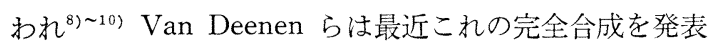
している ${ }^{11}$ 。

クジラ資源の利用という見地からナガスクジラ心筋か らカルジオリピンを抽出し，これが梅毒血清反応用の試 薬（抗原）として充分に使用できることがわかったので 報告したい。

\section{2 実験}

\section{$2 \cdot 1$ 実験材料および実験方法}

原料は冷凍したナガスクジラの心臟で，これを室温で 溶融してから, アセトン中で細粉し,さらにアセトンで 脱脂, 脱水した乾燥細粉を 95\%-メタノールで室温で抽 出した。メタノール抽出は2 回行ない, 抽出液を一緒に して Fig.-1 に示す Pangborn ${ }^{4}$ の過程により精製し た。

溶剂はすべて蒸留, 精製したものを用いた。

つぎに分析関しては, リンは King 法 ${ }^{12)}$, 窒素はミ クロケルダール法, ヨウ素価は臭化ピリジンを用いる安 田法 ${ }^{13)}$, 赤外線吸収スペクトルは EPI- $\mathrm{S}_{2}$ 型装置(日立 製）を用い，ブロムカリ法によった。

T.L.C. は一般方式 ${ }^{14}$ 亿従い, 溶淳系はクロロホルムー メタノールー水 $(65: 25: 4)$ で, リン脂質はモリブデン ブルーによるリンの発色により，また脂質全体は硫酸噴 霧後力(煆)焼して調べた。

ガスクロマトグラフィー (G.L.C.) のために, C.L. 到 $1 \mathrm{~N}$-塩酸, メ夕ノール溶液に溶解し, $60^{\circ} \mathrm{C}, 1 \mathrm{hr}$ 静 置してメタノリシスを行なった。なお， G.L.C.の装置 は Kotaki GU-12 型で, 条件は,

カラム : polyethylenglycol succinate (担体 Celite 


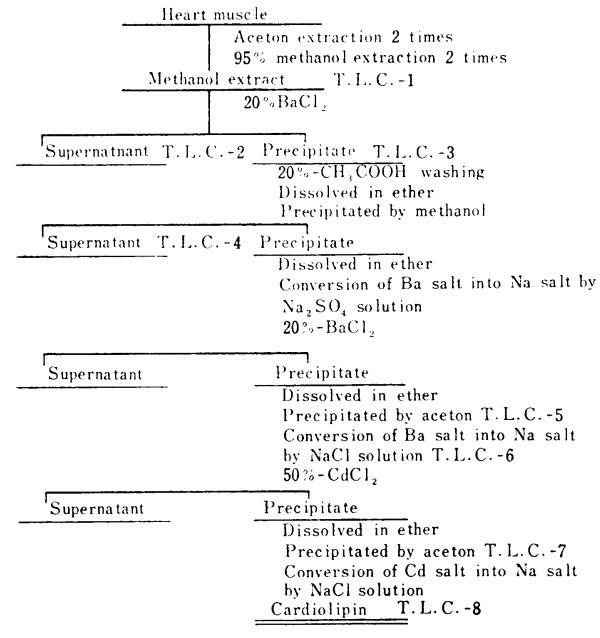

*T. L.C. -1, T. L.C. -2 , etc corresponded to the numbers in Fig. -2 .

Fig.-1 Procedure of cardiolipin preparation.

$$
\text { 545) } 2 \mathrm{~m}, 210^{\circ} \mathrm{C}
$$

キャリヤーガス：ヘリウム, 流速 : $50 \mathrm{ml} / \mathrm{min}$

\section{$2 \cdot 2$ 実験結果および考察}

Fig.-1 に示す精製法の各段階に㧍ける精製の度合は Fig.-2の T.L.C. に示す。

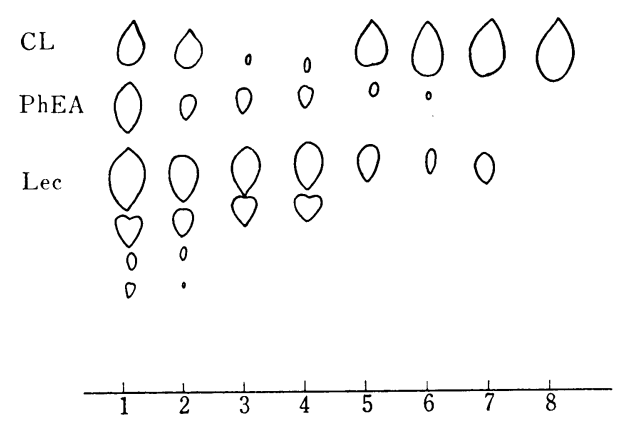

The numbers in Fig. -2 presented the step of purification procedure.

Fig.-2 T.L.C. of phospholipid in each step of purification.

Fig.-2 に示すように各段階においてレシチン，ケフ アリンを除去されていくことがよくわかる。しかし， Ba-C.L. および Cd-C.L. をエーテル, アセトンで処理 するとき，かなりの量の C.L. が逃げており，この回収 を考えないと収率をあげるわけにはいかない。この点, Gray, MacFarlane らあるいはその他の研究者による ケイ酸カラムクロマトグラフィーによる C.L. の抽出精 製の収率 ( $0.5 \mathrm{~g} / 1 \mathrm{~kg}$ 新鮮ウシ心臟) は非常に良いとい える。精製した C.L. は Table-1 のような化学分析值 を有している。

この C.L.の赤外線吸収スペクトルは Fig.-3 に示す
Infrared spectrum of the

fin whale $\mathrm{CL}$

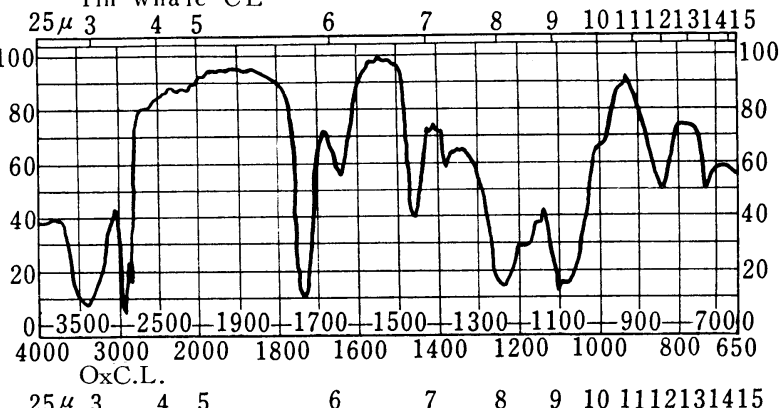

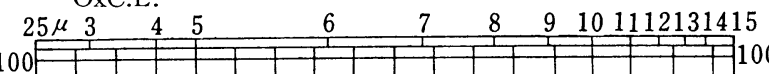

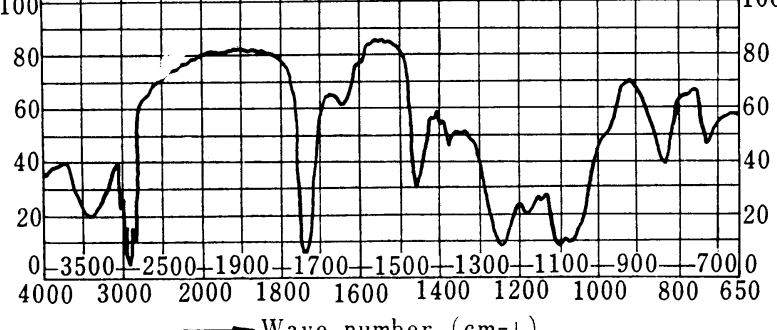

$\longrightarrow$ Wave number $\left(\mathrm{cm}^{-1}\right)$

Fig.-3 IR spectra of cardiolipin.

Table-1 Chemical analysis of cardiolipin.

$\mathrm{P}(\%) 4.2, \quad \mathrm{~N}(\%)<0.1, \quad$ I.V. 107

ようにウシ C.L.のと良く一致し，スペクトルのパター ンと構造式との矛盾はない。

つぎに C.L.の脂肪酸分布をみるために, 上述の方法

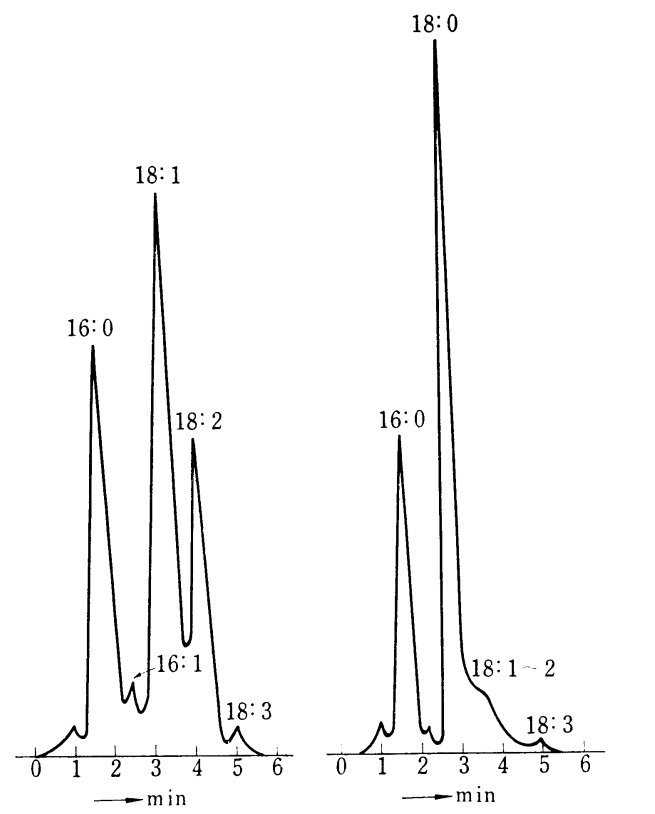

Fin whale cardiolipin After hydrogenation methyl ester

Fig.-4 G.L.C. of fatty acid methyl ester of cardiolipin. 
によって脂肪酸のメチルエステルを作り，これを G.L. C. にかけた。さらに脂肪酸のメチルエステルを Adams の白金触媒を用いて水素添加した。これらの試料の G. L.C.のパターンは Fig.-4 に示す。

Fig.-4の図型から計算すると，分取された脂肪酸の 組成はパルミチン酸 $23.5 \%$ ，パルミトレン酸 $4.6 \%$, オレイン酸 $44.5 \%$ ，リノール酸 $25.0 \%$, リノレン酸 $1.4 \%$ であって，これ以上長鎖の脂肪酸はみられない。 この組成を C.L.の式にあてはめるとその分子式は $\mathrm{C}_{19}$ $\mathrm{H}_{146} \mathrm{O}_{17} \mathrm{P}_{2}$ となる。パルミトレン酸, リノレン酸が少 量あることを考慮に入れても，計算による I.V. は約 80 となり，測定された I.V.107 よりはるかに低い。 これはメチルエステルの分取が悪く, リノール酸をある

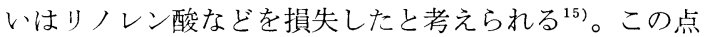

Table-2 Serological reactions for syphilific sera with cardiolipin of fin whale.

Composition of antigen Cardiolipin $0.03 \%$

Lecithin $\quad 0.17 \sim 0.19 \%$

Cholesterol $0.90 \%$

\begin{tabular}{r|c|c|c|c}
\multicolumn{1}{c|}{ Antigen } & Ox C.L. & \multicolumn{3}{|c}{ Fin whale C.L. } \\
\hline Lecithin\% & 0.18 & 0.17 & 0.18 & 0.19 \\
\hline Serum No. 1 & H & H & H & H \\
2 & $H$ & $H$ & $H$ & H \\
3 & + & + & $H$ & $H$ \\
4 & $H$ & $+H$ & $H$ & H \\
5 & $H$ & H & H & H \\
6 & + & + & H & +
\end{tabular}

については目下再検討中である。

つぎにこの C.L.の生化学的性状である梅毒血清反応 における抗原性については，Table-2 に示すように V DRL 方式によってウシ C.L. と比較しながら，調合 し, それらの梅毒陽性血清との反忘をみると, 両者とも よく一致し，また Table-2 には省略したが梅毒陰性血 清とは反応せず, 実用上, 本 C.L. が充分目常の検査に 用いられらることを示している ${ }^{16)}$ 。

油化学研究発表会 発表 昭和 40 年 10 月（東京） (昭和 40 年 11 月 9 日受理)

\section{文献}

1）五十嵐，座間，片田，農化，30，110（1956）

2）五十嵐，座間，片田，農化，30，116（1956）

3) 佐野, 鮎川, 村瀬, 油化学, 14, 171 (1965)

4) M.C. Pangborn, J. Biol. Chem., 143, 247 (1942)

5) M. Faure, Bull. Soc. Chim. Biol., 30, 333 (1948)

6) 原, 日化, 76, 910 (1955)

7) G.M. Gray, M.G. MacFarlane, Bioch. J., 70, 409(1958)

8) E. Baer, J. Biol Chem., 198, 853 (1952)

9) 野島, 井上, 日本脂質生化学研究会第 7 回研究会発表 昭 40.6 月

10) 原, 金子, Bull. Soc. Chim. Biol., 46, 339 (1964)

11) G.H. de Haas, L.L.M. van Deenen, Rec. Trav. Chim., 84, 436 (1965)

12) E.J. King, Bioch. J., 26, 292 (1932)

13) M. Yasuda J. Biol. Chem., 94, 401 (1931 2)

14）金子, 川西, 油化学, 12, 597 (1963)

15) L.W. Wheeldon, Z. Schumert, D.A. Turner, J. Lipid Rer., 6, 481 (1965)

16) 緒方“梅毒の新しい血清学的検查江:”第 2 版 p. 37 (1954( 南山堂

\title{
高級脂肪酸エステルと短鎖第三アミンを
}

\section{原料とする高級第三ア之ンの製造}

\author{
池田功・阿 河利男 -小森三 郎 \\ 大阪大学工学部応用化学教室 (大阪市都島区東野田)
}

\author{
Preparation of Higher Tertiary Amine from Higher Fatty \\ Acid Ester and Lower Tertiary Amine \\ Isao IkedA, Toshio Agawa and Saburō Komori \\ Faculty of Engineering, Osaka Univ. (Higashinoda-chō, Miyakojima-ku, Osaka)
}

Mono higher alkyl tertiary amine was prepared by a new one-step process from fatty acid ester: $\mathrm{RCOOR}^{\prime}+\mathrm{R}_{3}{ }^{\prime} \mathrm{N} \stackrel{\mathrm{H}_{2}}{\longrightarrow} \mathrm{RCH}_{2} \mathrm{NR}_{2}{ }^{\prime}+2 \mathrm{R}^{\prime} \mathrm{OH}$

Ethyl laurate and triethyl amine were reacted at the condition of hydrogenolysis in an autoclave. Good yield (83\%) of diethyl lauryl amine was obtained at $200 \sim 250 \mathrm{~kg} / \mathrm{cm}^{2}, 300^{\circ} \mathrm{C}$ for $3 \mathrm{hrs}$ using $15 \sim 20 \%$ of $\mathrm{Cu}-\mathrm{Cr}-\mathrm{O}$ catalyst to raw ethyl laurate, and $5 \sim 7$ mols of triethyl amine to $1 \mathrm{~mol}$ of raw ester. 